\title{
Reflecting on European Migration and Refugees: From a Feminist Perspective
}

\author{
Kathrin Winkler \\ Lutheran University of Applied Sciences Nuremberg, Germany
}

\begin{abstract}
Women come to Europe from the Middle East, from Africa and other threatened regions. In many cases, they bring their religion with them —as Muslim women, Yezidi women or as Christian women, alone or with their children and their families. Seeking refuge is a process of change for themselves as well as for the European societies. What kind of experiences do women gain during and after their flight? Are there experiences that are specific to women? The insights into the reality of fleeing women lead to existential philosophical reflections. Hannah Arendt's definition of humanity and the right to have rights is relevant to current migrants' experiences. Intersectionality examines the multiple discriminations and social inequality of women seeking asylum in Europe. On the basis of political theory Seyla Benhabib clarifies that the right to have rights is inexorably dependent on whether social acceptance has been granted or not. To analyze these questions, the requirements of and advantages to European societies must be defined. And how can this line of inquiry be used to develop a politically motivated theology?

Keywords: women and migration, Europe, intersectionality, human rights, social philosophical concepts, feminist perspectives, political theology
\end{abstract}

\section{Recent Studies on Women on the Run in Europe-Interpretations}

Women comprise slightly less than half of all international migrants. Female migrants outnumber male migrants in Europe and Northern America, while in Africa and Asia, particularly Western Asia, migrants are predominantly men. ${ }^{1}$ Three current studies, which focus on women as refugees, provide insight into the situation in Europe.

The UNHCR Report "Woman Alone - the Fight for Survival by Syrian Refugee Women” is based on the personal testimony of 135 women, given over three months of interviews in early 2014.2 This study was designed to document and understand what life is like for these women and to understand the specific challenges they face. Forced to take sole responsibility for their families after their men were killed, captured or otherwise separated, they are caught in a spiral of hardship, isolation and anxiety. The report describes daily struggles to make ends meet, to maintain their dignity and to care for their families in extreme conditions like run-down and overcrowded homes, insecure makeshift shelters and tents. Many of the women in transit camps live under the threat of violence or exploitation and their children face mounting trauma and distress. Life in exile for these women has meant becoming the primary breadwinner and caregiver, fending for themselves and

Kathrin Winkler, Ph.D., Professor, Religious Studies/Religious Education, Lutheran University of Applied Sciences Nuremberg. ${ }^{1}$ http://www.un.org/en/development/desa/population/migration/publications/migrationreport/docs/MigrationReport2015_Highlight s.pdf.

2 http://www.unhcr.org/ar/53bb8d006.pdf. 
their families, away from their communities and traditional sources of support. For most, the burden is overwhelming, and many are entirely dependent on outside assistance.

Amnesty International reported in January 2016 on sexual violence against and exploitation of female refugees. ${ }^{3}$ Many women fleeing Syria and Iraq experienced violence, exploitation and sexual harassment by smugglers, male refugees and also by European security guards. The concrete problems women face in refugee and transit camps are:

- no safe sleeping places;

- inadequate medical care of pregnant women and mothers;

- sexual harassment;

- unhygienic environment;

- violence.

Amnesty International interviewed 40 women in Germany and Norway, who fled from Turkey to Greece and then over the Balkan route to Western Europe. All of them described that they felt insecure, humiliated and threatened, that they experienced physical violence and financial exploitation in nearly every country they had to go through.

Tirana Hassan, the director of the crisis intervention team of Amnesty International summarized: "After living through the horrors of the war in Iraq and Syria these women have risked everything to find safety for themselves and their children. But from the moment they begin this journey they are again exposed to violence and exploitation, with little support or protection."

The third study is from the network "Research of Refugees" and focuses on refugees as political actors. ${ }^{5}$ What does this mean? The situation of thousands of refugees at the rail station in Budapest in Fall 2015 is a prime example. They were stranded at the station, controlled and refused entry to the trains. As a result the refugees could not cross the border legally to a country of the Schengen area. So in Hungary they were regarded as illegal. Even if they had a rail ticket, they were not permitted passage. After endless waiting and arbitrary actions, thousands of refugees took their destiny in their own hands. Encouraged by the suspension of the Dublin II regulations, thousands of them took the road to other European countries, especially to Germany. They refused to subject themselves to the restrictions of Hungarian controllers, rather they actively resisted the state regulations. Without the official right of free movement, the refugees took their rights in a kind of performative act. They demonstrated: “When we walk, we make our decision. We don't wait for the others to give us solutions". ${ }^{6}$ They taking the right of free movement shed a bright light on the conflicts relating to borders in democracies. The unregistered immigrants represent the fight for this human right.

There are myriad reasons why women flee their countries. Women are driven to flee because they suffer from civil war, political and religious persecution or severe economic conditions. It is common to all, that they feel forced to undergo the pain of migration to escape (Manemann, 2012, p. 207f). The decision to migrate is neither simple nor easy.

Migration, escape and exile have become a basic experience of being in the world. This is true for the present situation, but also for many other situations in history. The Jewish philosopher Vilèm Flusser

3 http://www.amnesty.org/en/latest/news/2016/01/female-refugees-face-physical-assault-exploitation-and-sexual-harassment-on-theirjourney-through-europe/

4 a.a.O.

${ }^{5}$ http://fluechtlingsforschung.net/neuburger_innen-europas/

${ }^{6}$ http://www.theguardian.com/world/video/2015/sep/10/we-walk-together-a-syrian-familys-journey-to-the-heart-of-europe-video 
formulated it based on his own exile experiences caused by the 2nd World War:

Someone who leaves the home country (whether forced or freely chosen and they are often difficult to distinguish) suffers. Because thousands of strings connect him with the home country, and if these are cut, it is as if a surgical intervention has taken place. (Flusser, 2013, p. 10)

And then? What actually happens to men, women, children, and youths during the flight?

Hannah Arendt ascertained it more than 70 years ago with a shocking timeliness for us today. She said:

We lost our home, which means the familiarity of daily life, we lost our occupation, which means the confidence that we are of some use in this world. We lost our language, which means the naturalness of reaction, the simplicity of gestures, the unaffected expression of feelings. We left our relatives in the Polish ghettos and our best friends have been killed in concentrations camps, and that means the rupture of our private lives. (Arendt, 1943, p. 110)

These few lines are from Hannah Arendt's essay We Refugees, a short text published in January 1943 in the Menorah Journal. The short description of the loss of professional existence and meaningfulness in this world, the loss of language and emotionality has not lost any of its relevance today. Based on her own fate as a refugee, Arendt developed for the first time in her book "The Origin of Totalitarianism" the thesis that humanity means the right to have rights.

The circumstances, as Hannah Arendt described them, have changed only little for refugees in the 21st century. Like the refugees in the 20th century, it is a fact that they are declared outlaws based on their birth. Arendt interprets this as a situation of innocence, which is punished with rightlessness. Another common characteristic of these "modern refugees" of both centuries is their hopelessness, because recognition is made impossible even in the new home country. According to Hannah Arendt, refugees can be defined till this day as stateless persons and disenfranchised people, who are reduced to their bare life. Nobody is interested in them and their lives (Arendt, 1951, pp. 266-298). For women, the situation is especially precarious, because they are subjected to discrimination in various forms.

\section{The Female Face of Migration and Feminist Questions}

Sixty million people worldwide are on the run and according to the United Nations every second refugee is female. It is a fact in this 21st century: Never before have so many people been forced to leave their home country, never before has the right to have rights been at stake for so many people. Furthermore, the situation of women on the run requires special consideration. The social experiences and positions of women in migration differ fundamentally from those of men.

Migration research ignored migrating women for a long time. First, the research viewed migration as a genderless or then as a male phenomenon. Only since the 1980s have women and their context of migration stood in the focus of studies. In the 1990s, research was initiated into the circumstances and importance of gender in migration (Diehm, 2013).

Because they are women they have specific working and life situations in their home country as well as in their destination country, which are distinct from those of men. To clarify, it is helpful to use some feminist concepts.

\section{Intersectionality as an Instrument of Reflection}

Gender is a central structural principle of migration beside ethnicity, nation, social class, culture and religion. Social inequality and discrimination can be seen across these categories which also have mutual 
interactions (Lykke, 2010). The perception of the interactions between these discrimination categories is called "intersectionality". The term originated from the feminist movement of Black women in the USA and is also critically discussed in Germany in feminist theory and gender studies. The concept first came from legal scholar Kimberlé Crenshaw in 1989 and is largely used in critical theories, especially feminist theory, when discussing systematic oppression. Intersectionality is a concept often used in critical theories to describe the ways in which oppressive systems (racism, sexism, homophobia, transphobia, ableism, xenophobia, classism, etc.) are interconnected. Intersectionality can be defined as social categories which cannot be examined separately from one another, but have to be analyzed for their entanglement and their intersections. In this context, Judith Butler criticized the enumerations. The number of categorizations of a subject is never complete. Additive perspectives should be overcome by placing the focus on the combination of social inequality (Butler, 2008); it is about the precise analysis of interactions (Carastathis, 2016).

What does this mean for female refugees? In spite of critical discussions, intersectionality can be useful in analyzing power and dominance relationships, which are the source of social inequality and discrimination for fleeing women, for example rape, forced prostitution and exclusion from education or medical care (Spies, 2012, pp. 105-125).

Intersectionality is also very useful in analyzing the connections between culture, social injustice and rightlessness as related to women in migration. Inside the feminist discourse about women and migration, critical female migrants refer to a number of problems that specifically affect migrant women which are not included enough in feminist discussions. Here some examples of their criticism:

(1) The consequences of a so-called dependent right of residence, which depends on the husband.

(2) The critical need to recognize female reasons for asylum like sexist persecution, rape and gender-based discrimination or homosexual discrimination.

(3) The assumption of social reproduction work in western households by female migrants from the South or East of Europe.

(4) The tokenistic engagement of female migrants in women's projects.

(5) The discriminatory and dichotomic hierarchic contrast of modern, western and Christian positions and traditional, Islamic positions.

(6) Western feminist attitudes lead to a devaluation of the perceived level of emancipation of so-called Third-world women (Walgenbach, Dietze, Hornscheidt, \& Palm, 2012, pp. 23-64).

Analysis of these special contextual situations of female migrants and their discriminatory intersections leads to further reflections.

\section{The Right to Have Rights}

Hannah Arendt, herself a refugee, summarized:

We became aware of the existence of a right to have rights (and that means to live in relationships where one is judged by one's actions and opinions) and a right to belong to some kind of organized community, only when millions of people emerged, who had lost these rights and could not regain these rights because of the new global political situation. (Arendt, 1951, p. 294)

The situation of the refugees at that time, like today, demonstrates clearly, how difficult it can be to implement the universal claim to human rights in reality. Even one of the most central human rights, the right to human dignity, has been lost by excluding refugees, as Arendt said. 
Likewise the equality, with which everybody is born, according to the declaration of human rights, is ignored by exclusion from the community as well as by the affiliation to nationalities. Refugees seem to be a kind of paradox of the modern nation state, which wants to exhibit a uniform legal form, but at the same time excludes some people who stay within its borders from this community (Meints-Stender, 2007, pp. 251-258).

The political scientist Seyla Benhabib has made, in connection to Arendt, the conflict between sovereignty of nation states and the claim of human rights a subject of discussion. Especially the figure of the refugee plays a key role. The position of the refugee is characterized by exclusion from any community and existing legal systems, what is especially true for fleeing women.

Seyla Benhabib directs special attention to the contrariness of moral claims of liberal democracies and the failure to realize these claims in practice, especially relating to the refugee problem. The right to have rights, as Arendt formulated, presently can be redeemed only by him or her, who posses social acceptance. That means rights are dependent on the legal status of a person in a certain community. Benhabib concludes her discussion by relating Arendt and Kant: The right to have rights and also the responsibility that results therefrom have an moral claim, because they are ascribed to human beings across all boundaries and differences of culture, religion, language etc. (Benhabib, 2004, p. 64).

The right to have rights is ascribed to all human beings without distinction and it pertains to the social problem of our time: People are divided and separated, are sorted to identity and difference, split into concepts and skin colors, into origin and religion, into sexuality and body, to justify exclusion, power and violence. Individual diversity and normative equality must apply in order to ensure the right to have rights.

\section{Perspectives of Political Theology}

Theology must face this claim, because it belongs to its basic topics. In this case it is a specific theological approach to view migration and flight as a special source for developing theology, for transforming theology and of new insight into theology. The social challenges can be viewed as opportunities for theological insights.

Political theology investigates the ways in which theological concepts and ways of thinking relate to politics and society. Viewing the influences of liberation theology and contextual theology on political theology, four implications arise: Certain perspectives within a specific context must be analyzed; the present human experience(s) must be recognized as a locus theologicus; justice, freedom and equality must be analyzed from a theological point of view; and the importance and value of religions must be advocated in secularized societies (Joas, 2007). These implications lead to different prospects, especially for women.

On the one hand religion and migration can be understood as an opportunity for change and reform: democratic societies could learn much from their effects. Social-philosophical approaches ask whether and to what extent religion is a source of value orientation and common good. Is it possible to achieve a so-called overlapping consensus between different religious and worldview communities (Rawls, 1993 [2005])? What does it mean for the religious and worldview communities and the women to agree to freedom, gender equality and human rights from their own perspective? In addition, it is also important to investigate the significance religion has in the integration process for women and their families (Elwert, 2015; Beyme von, 2015).

On the other hand migration can be a source of theology. This means firstly to respect migration as a space of faith and believing, particularly for women. Secondly, migration is a kind of test of theology; the meaning and claim of lived religion can be questioned and opportunities for interreligious communication in immigrant societies arise. Thirdly, migration can be understood as a field of application of theology. Theology informs 
and is informed by social sciences, society and politics and different views on migration are incorporated into discussions within the field. This dialog includes mutual critique and advancement of knowledge. Not least, theology in situations of migration is contextual theology with specific social and political contexts. Migration exposes global injustice, oppression and unfreedom which require responses from a theological perspective (Castles \& Miller, 2007).

\section{Conclusion}

Women who are fleeing to Europe are border-crossers. Voluntarily or involuntarily they leave their well-known homeland and venture on a risky future. The border crossing of these migrant women provides an impetus for change in the traditional thinking patterns and habits in European societies and religious communities. With their specifically female experiences and perspectives they must translate from one culture and religion into another. This act of translating broadens their own horizon and potential, but remaining an outsider also increases the risk of discrimination and oppression. So what can we do? Hannah Arendt wrote in the Human Condition: "With words and deeds we insert ourselves into the human world, which exists before our birth, and this insertion is like a second birth, in which we confirm and take upon ourselves the naked fact of our original physical appearance and take responsibility for this. This insertion is not forced upon us by necessity, like labor, and it is not prompted by utility, like work. (...)To act, in its most general sense, means to take an initiative, to begin, to set something into motion” (Arendt 1958, p. 176f). To begin something new on one's own initiative is the sign of the times.

\section{References}

Arendt, H. (1943). We refugees. In R. Marc (Ed.), Altogether Elsewhere: Writers on Exile. London and Boston: Harvest.

Arendt, H. (1951). The origins of totalitarianism. New York: Hartcourt, Brace and Company.

Arendt, H. (1958). The human condition. Chicago: University of Chicago Press.

Benhabib, S. (2002). The claims of culture: Equality and diversity in the global era. Princeton, N.J.: Princeton University Press.

Benhabib, S. (2004). The rights of others: Aliens, residents and citizens. Cambridge: Cambridge University Press.

Benhabib, S. (2011). Dignity in adversity: Human rights in troubled times. Cambridge, UK: Polity.

Beyme von, K. (2015). Religionsgemeinschaften, Zivilgesellschaft und Staat (Religious communities, civil society and state). Springer Wiesbaden.

Butler, J. (2008). Gender trouble: Feminism and the subversion of identity. New York: Routledge.

Carastathis, A. (2016). Intersectionality: Origins, contestations, horizons. Nebraska: University of Nebraska Press.

Castles, S., \& Miller, M. J. (2007). The age of migration: International population movements in the modern world. New York/London: Guilford Press.

Diehm, I. M. (2013). Das Geschlecht der Migration: Bildungsprozesse in Ungleichheitsverhältnissen (Gender and migration: Educational processes in relations of inequality). Verlag Barbara Budrich Opladen/Berlin/Toronto.

Elwert, F. (2015). Religion als Ressource und Restriktion im Integrationsprozess (Religion as a resource and restriction in integration process). Wiesbaden: Springer.

Flusser, V. (2013). Von der Freiheit des Migranten: Einsprüche gegen den Nationalismus (On the Freedom of a migrant: Objections against Nationalism). Europäische Verlagsanstalt Hamburg.

Gündogdu, A. (2015). Rightlessness in an age of rights: Hannah Arendt and the contemporary struggles of migrants. New York: Oxford University Press.

Hancock, A. M. (2016). Intersectionality: An intellectual history. New York: Oxford University Press.

Joas, H. (2007). Braucht der Mensch Religion? Über Erfahrungen der Selbsttranszendenz (Do humans need religion? About experiences of self-transcendence). Herder Verlag Freiburg i.Br.

Lykke, N. (2010). Feminist studies: A guide to intersectional theory, methodology and writing. London: Routledge. 
Manemann, J. (2012). Migration und Exodus (Migration and exodus). In Ders./Schreer, Werner (Hg.), Religion und Migration heute: Perspektiven - Positionen - Projekte (Religion and Migration Today: Perspectives - Positions - Projects). Regensburg Schnell \& Steiner Verlag.

Meints-Stender, W. (2007). Hannah Arendt und das Problem der Exklusion - eine Aktualisierung (Hannah Arendt and the problem of exclusion). In Heinrich-Böll-Stiftung (Hrsg.), Hannah Arendt: Verborgene Tradition - Unzeitgemäße Aktualität? (Hannah Arendt: Hidden Tradition - Outmoded Actuality?). Berlin.

Rawls, J. (1993 [2005]). Political Liberalism. NY: Columbia Press.

Spies, T. (2012). Gewalt, Geschlecht und Ethnizität: Intersektionalität im diskursiven Kontext (Violence, gender and ethnicity: Intersectionality in a discursiv context). In B. Mechthild (Hg.), Migration und Geschlecht. Theoretische Annäherungen und empirische Befunde, Beltz Juventa Weinheim (Theoretical approaches and empirical results).

Walgenbach, K. (2012). Intersektionalität als Analyseperspektive heterogener Stadträume (Interesctionality as a perspective of analysis in Heterogeneous urban spaces). In Scambor, Elli/Zimmer, Fränk (Hg.), Die intersektionelle Stadt. Geschlechterforschung und Medien an den Achsen der Ungleichheit (The Intersectional City: Gender research and media at Axes of InequalityBielefeld).

Walgenbach, K., Dietze, G., Hornscheidt, L., \& Palm, K. (2012). Gender als interdependente Kategorie: Neue Perspektiven auf Intersektionalität, Diversität und Heterogenität, Verlag Barbara Budrich Opladen/Berlin/Toronto (Gender as a Interdependent Category: New perspectives on intersectionality, diversitiy and heterogeneity). 